\title{
THE GEOLOGY OF THE NEIGHBOURHOOD OF FORT WILLIAM.*
}

BY E. B. BAILEY, B.A., F.G.S.t

(Rend July $7 t h$, rgIt.)

CONTEXTS.

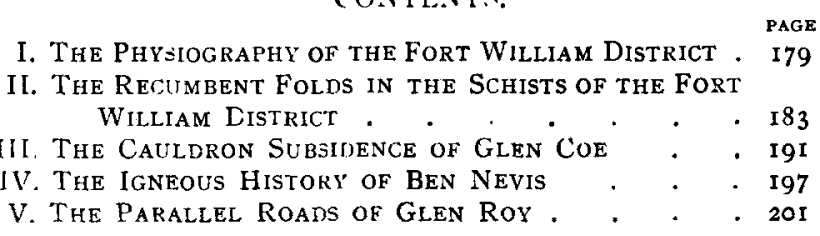

TH

$\mathrm{HE}$ purpose of the present paper is to give a bird's-eye view of some of the more interesting geological phenomena presented by the Fort William district. For details the reader is referred to the various papers mentioned in the bibliography (see p. 203), and especially to the Geological Survey map (Sheet 53) and memoir which, it is hoped, will be published very shortly.

Plates XXIII and XXVII and Figs. I2, I3, and $\mathrm{I}_{4}$ are reproduced by permission of the Geological Society of London. Pl. XXVI is slightly modified from the original form published by the Geological Society, and the reason of the change is explained in a note at the end of the section dealing with the Schists. Apart from this note the present paper must be regarded merely as a compilation. Plates XXIV and XXV are from photographs by Mr. R. Lunn, of the Geological Survey of Scotland.

\section{I.-THE PHYSIOGRAPHY OF THE FORT WILLIAM DISTRICT.}

The region described is a mountainous tract, divided into two by a great continuous hollow, which is for the most part occupied by the waters of Loch Linnhe. Loch Leven, a branch fjord joining Loch Linnhe from the east, further subdivides it, though less completely. The whole is a much-dissected portion of the main Highland plateau. The summits and ridges east of Loch Linnhe constantly attain an altitude of about 3,000 feet (Pl. XXVIII), Ben Nevis, 4,406 feet high, and certain other

* Advance copies of this paper vere issued to members in connection with the Long Excursion of igr 1 .

+ By permission of the Director of the Geolcgical Survey.

Proc. Geol. Assoc., Vol.. XXII, Part 4, Igir.] 
massifs raise themselves notably above this general level and may well represent ancient monadnocks or islands never levelled down with the rest of the plateau.

West of Loch Linnhe the normal summit level for the dissected plateau is about 2,500 feet, that is some 500 feet lower than on the east. The cause of this difference is not as yet apparent.

The drainage system of the high plateau was initiated in Tertiary times, at some period subsequent to that of the outpouring of the basaltic lavas of the Hebrides. This fact has been repeatedly emphasised by Sir Archibald Geikie in regard to the West Highlands in general, and is well illustrated in the manner in which many valleys, such as Glen Tarbert on the west side of Loch Linnhe, have been cut through Tertiary basalt dykes. Among the most striking features of this drainage system is the prevalence of through and hanging valleys. The former are of two kinds : some have clearly been determined by the structure or grain of the country, while others, so far as one can judge, are altogether independent of this structure.

The type of through valley determined by structure is most strikingly illustrated by certain "shatter-belt" valleys-a valuable term introduced by Dr. Marr. Loch Linnhe marks the course of part of one such shatter-belt valley, the Great Glen, which can be followed from side to side of Scotland; another shatter-belt valley is that of Loch Leven and Loch Eilde Mor; yet another determines the upper part of Loch Etive, the lower part of Glen Etive, the Lairig Gartain, and a whole series of minor streams north of Glen Coe.

The type of through valley which is independent of geological structure is well represented on both sides of Loch Linnhe; on the north-west lie Glen Scaddle, Glen Gour, and Glen Tarbert : on the south-east, Glen Nevis, the Lairigmor and River Leven Valley, and Glen Coe.

Following Cadell, Mackinder, Peach, and Horne, we regard through valleys of this second type as relics of a once continuous drainage system leading more or less from west to east, a drainage system which is now in large measure interrupted and segmented owing to the development of subsequent valleys along special lines of weakness. Others of course regard these through valleys as due to glaciation; for a discussion of this and similar debateable matter the reader is referred to the Geological Survey Memoir.

In Pl. XXVIII expression is given to the interpretation of the through valley system which is here adopted. It may be urged by some that the correspondence of the through valleys on the north-west of Loch Linnhe with those on the south-east, as shown in this plate, is fanciful; but the same principle is involved in regard to the former connection of the Lairigmor 
and River Leven Valleys, now separated by the valley of Loch Leven, and it is so clearly vindicated in this case that it cannot reasonably be disputed.

Once a river system has been segmented by the encroachment of subsequent streams along such lines of weakness as the Loch Linnhe and Loch Leven shatter-belts, secondary watersheds must originate as a matter of course in the isolated segments. These secondary watersheds are often developed through the accumulation of material in the form of deltaic cones or of landslips. Delta-watersheds, or corroms as they are termed, may thus attain a great significance. The word corrom, employed above, is based on the Gaelic cothrom, a balance, and is of local origin. The stream issuing upon the col of Glen Tarbert is known as Alit a' Chothruim (the burn of the balance), since, at its point of entry, it has built up a great cone, upon which it is balanced, as it were, with the possibility of flowing either east or west. While the name corrom was taken from this Glen Tarbert example, it may be mentioned that it was first employed in descriptions of certain delta-watersheds of East Lothian, the physiographical importance of which was recognised by Professor Kendall. The divide at the head of Glen Nevis furnishes another good example of a corrom in the Fort William district.

Enough remains comparatively unaltered of the old valley system, as we may imagine it formerly existed, to show that it had reached a very mature condition of erosion before its segmentation. The flat upper reaches of the River Leven, where a dam impounds a reservoir some seven miles long, afford a striking illustration of this feature. The segmentation and resultant short-circuiting has, however, caused a partial rejuvenation of the ancient mature river system throughout a large part of the district, leading to the production of a typical hanging valley system. The condition of the River Leven recalls Mr. Lamplugh's descriptions of the Zambesi. The main river (which, by the way, is obsequent) has cut its waterfall back for more than three miles from its junction with the subsequent valley of Loch Leven. Beyond this point is the ancient topography, already referred to as including the site of the reservoir; the same ancient topography also persists almost intact on both sides of the rejuvenated portion of the Leven, save where it is cut into by two tributary valleys which join the main river a mile and a half from its mouth. The form of the rejuvenated portion of the Leven Valley, and, even more clearly, that of the tributary valley draining Loch Eilde Mor, seems to preclude ice as the agent of overdeepening.

In Glen Nevis the evidence is more complicated. The form of the main valley near Polldubh, and of two tributary valleys which join it with accordant grade at the same locality, speak against glacial overdeepening. At the same time certain of the 
tributary hanging valleys of this glen bear the unmistakable stamp of glacial modification. The most striking evidence of this action is afforded by a hanging valley, or corrie, which drains into Glen Nevis directly from the north, $1 \frac{1}{2}$ miles east of Polldubh. The waters of the powerful stream, issuing from this corrie, course down the slopes of Glen Nevis for a thousand feet. Looking along the side of the glen from the road, the tributary stream is seen standing out as a long ribbon of foaming water without any attempt at concealment; during post-glacial times it has not fashioned so much as a gorge wherein to shelter. The main valley at this point is of $U$-shaped cross section, unhampered by projecting spurs. It is scarcely conceivable that aqueous and subaerial erosion could have given this form to the main valley while at the same time the powerful lateral stream has accomplished nothing whatsoever on its own account. The explanation adopted in this case is that a pre-glacial hanging valley system has here been perfected as a result of glacial erosion : the Glen Nevis glacier opened up the main valley and removed the walls of the lateral gorge, through which, in pre-glacial times, the hanging valley drained. A similar explanation will account for a highly picturesque tributary waterfall cascading down an unnotched rock-face into Glen Nevis behind the keeper's house at Steall.

That glacial erosion is fully competent to open up main valleys in the manner suggested will scarcely be doubted by any who visit the district. PI. XXIV shows a roche moutonnée by the roadside in Glen Nevis about a mile above Polldubh. Here there is evidence not only of intense grinding but also of plucking-the importance of which has been emphasised by American geologists. A huge block has been picked out from the roche moutonnée, thus destroying the moulded contour of the latter, and morainic drift has been banked some little way up against the broken surface.

While extensive glacial overdeepening has not been recognised in the valleys of the Fort William district, it is not for a moment suggested that such has not occurred elsewhere in the Highlands. Of several convincing examples one need only refer to Loch Coruisk, in Skye, described in detail by Mr. Harker.

A word may now be added in regard to the probable origin of corries, which are represented by several magnificent local examples. The only agency at present at work in the district which might be held responsible for corrie formation is landslipping. Many important landslips occur, and behind the slipped material a hollow is often found, of semicircular form and backed by crags. Mr. Clough, in his description of the Cowal district of Argyllshire, has pointed out that hollows thus left by landslips often resemble corries ; in fact, some of the larger landslip hollows are actually small corries. He has further suggested that many of the crag features of Highland valleys may be due 


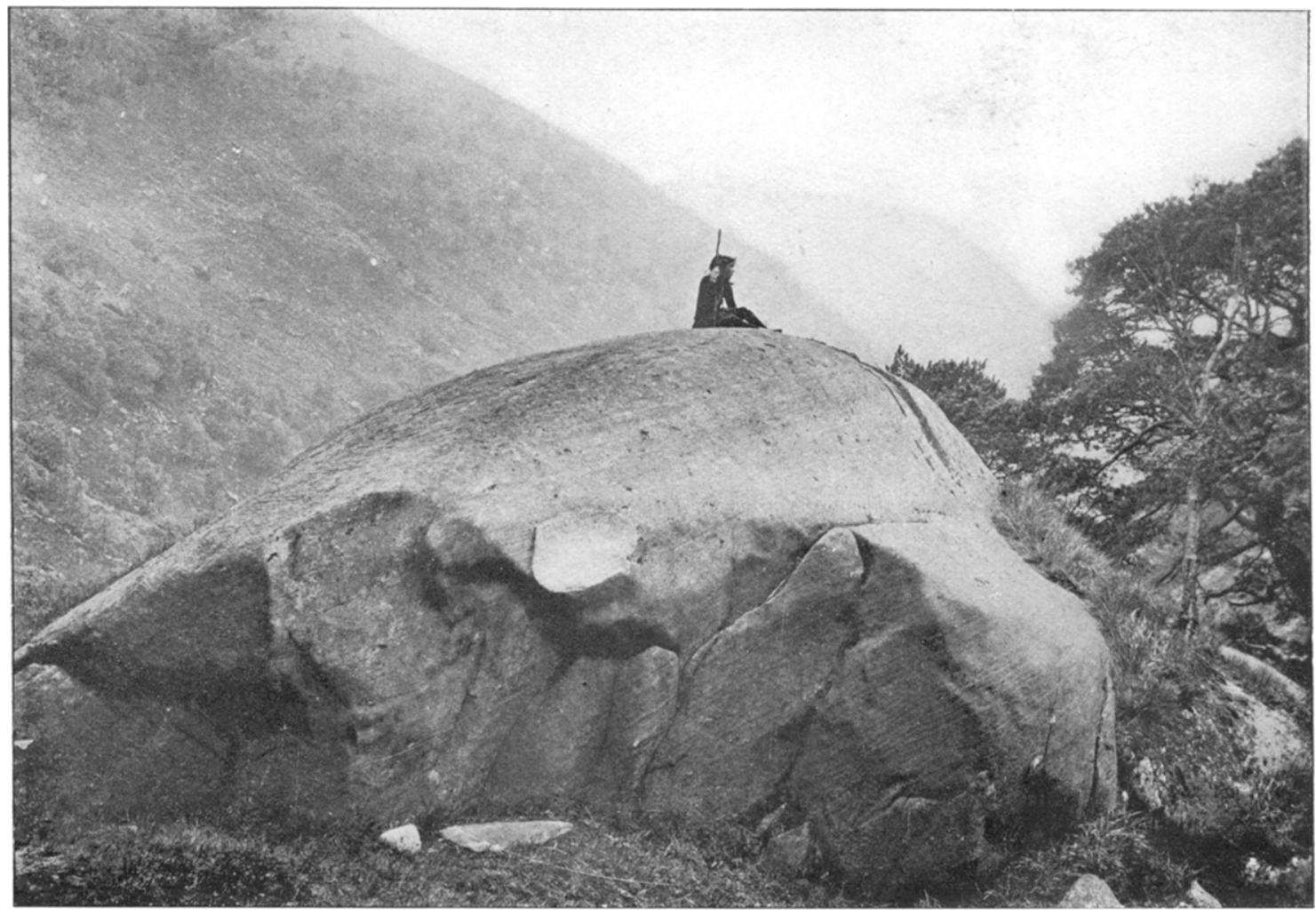

Roche Moutonnée Modified by "Plucking," Glen Nevis? 
to pre-glacial landslipping, followed by glacial removal of the fallen material. Such may well be the case.

It is probable that many of the landslips occurring in the present district are the result of unstable conditions due to glaciation. The sides of the valleys have been oversteepened by glacial erosion, and the landslips, unless their material is rapidly carried away, will ultimately correct this effect, although their inmediate result is often to produce cliffs and crags. A condition which would favour landslipping, and at the same time offer facilities for the transport of the slipped material, would obviously tend to produce corries and knife-edges. Such a condition is apparently afforded by glaciation. A glacier, near its head, sags away from the walls of the containing valley, and every summer the movement leads to the production of a great crevasse, the bergschrund of Alpine glacialists. The analogy between bergschrunds and the landslip cracks which occur so abundantly in some parts of the present district is very close. It is obvious, in fact, that the tug of the glacier before the bergschrund forms will be a powerful incentive to landslipping on a large and small scale, while it is equally obvious that the glacier will be an efficient carrier of slipped material. Johnson, who was the first to direct attention to the importance of bergschrunds in connection with corrie formation, laid stress upon the localised frost action of which he found evidence at the bottom of the crevasse; plucking, he states, likely supplements the initial rupturing due to the frost. According to the view outlined above, plucking is regarded as of prime importance, but it is obvious that the point is one to be settled by further observation on existing glaciers.

In this brief notice we have space only for one other feature in the physiography of the district, and it is one which is limited to the coast-line. A more or less continuous terrace, often backed by small cliffs, fringes the shores of Loch Linnhe and Loch Leven. It owes its origin to the combined effects of marme erosion and accumulation at a time when the land stood some $20 \mathrm{ft}$. or more lower than at present. The fertile beach deposits now raised above the sea have determined the sites of several coastal villages, while the terrace has allowed the making of roads, followed, of late years, by the railway which connects Ballachulish with the main Oban line.

\section{II.-THE RECUMBENT FOLDS IN THE SCHISTS OF THE FORT WILLIAM DISTRICT.}

The following stratigraphical sequence has been established in the crystalline schists of that portion of the Fort William district which is illustrated in Plate XXIII, but whether it 


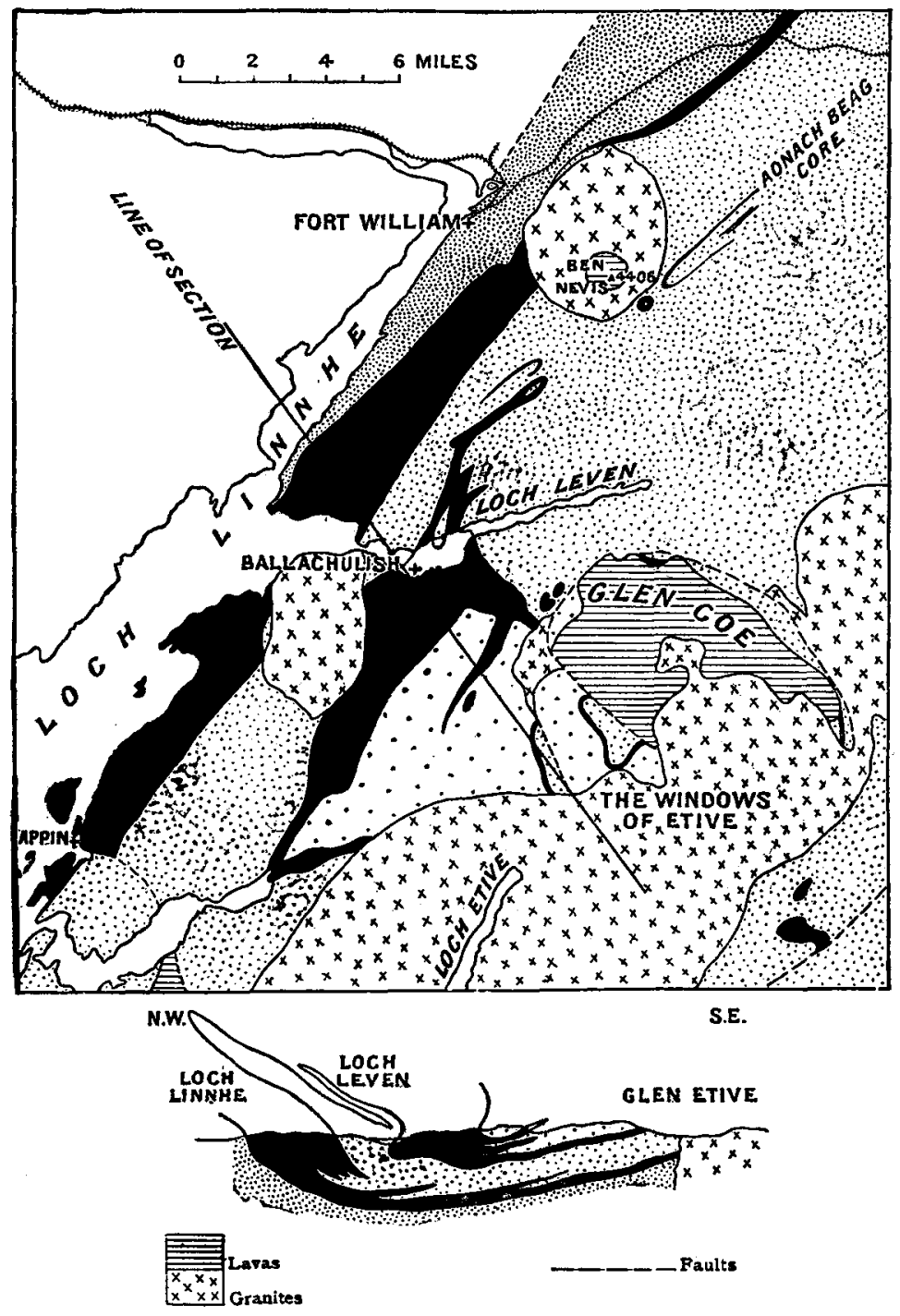

Groups $5-6$ of the table in the text,
included in, the Appin, Aonach Beag and Ballachulish Cores

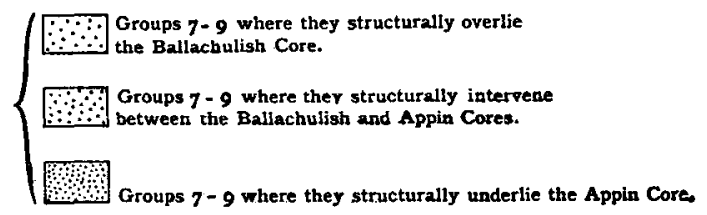

FIG. I2-SKeTCH-MAP SHOWING THE RELATIONS OF THE APPIN AND Ballachulish Cores. $-E$. B. Bailey. 
should be read upwards or downwards is a matter for future inquiries to decide :-

9. Eilde Flags (commonly classed with the Moine Gneisses of the Central Highlards).

8. Glen Coe Quartzite (fine-grained).

7. Leven Schists (grey phyllites, with "Banded Series" against Glen Coe Quartzite).

6. Ballachulish Limestone (dark grey, with thick pale grey and cream-coloured margin against Leven Schists).

5. Ballachulish Slates (black).

4. Appin Quartzite (pebbly).

4. Striped Transition Series (classed with the Appin Quartzite in Plates XXVI and XXVII, except in Sections F and G).

3. Appin Limestone (cream-coloured).

2. Appin Phyllites (with large proportion of flaggy quartzite).

1. Cuil Bay Slates (black).

No exact measurements can be given in regard to the groups tabulated above, but even the thinnest of them, the Appin Limestone, is probably not less than Ioo $\mathrm{ft}$. thick, while the Leven Schists, Glen Coe Quartzite, and Eilde Flags must each of them reach about $I, 000 \mathrm{ft}$. ; the other members of the sequence should doubtless be reckoned in hundreds of feet. These rough estimates refer to original thickness of deposition. Now over wide areas certain of the groups are reduced to mere films, or, may be, are entirely missing, as a result of the intensity of the folding movement to which they have been subjected; elsewhere, again, their dimensions have been mightily increased by reduplication-another aspect of the same folding process.

The details of the stratigraphy vouch for continuity of sedimentation during the formation of the great pile of deposit included in groups $1-8$, for all these groups are linked together by passagebeds. The Eilde Flags (9) also appear to be connected by a passage zone with the Glen Coe Quartzite $(8)$, but in this case further evidence is desirable.

It is unfortunate that there is nothing in the relations of the various groups to one another to afford a clue as to their original order of superposition; nor does the degree of their metamorphism assist in solving this difficult question. As a matter of fact there is increasing regional metamorphism in a south-east direction, which affects all groups alike, so that the Eilde Flags in the Loch Eilde Mor district are much more highly altered than the same flags in the Fort William district. While referring to metamorphism it is important to bear in mind that there are numerous granitic intrusions piercing the schists, each one surrounded by an aureole of marked contact alteration. In these aureoles many of the subdivisions assume very special characteristics, so much so that their definite correlation with the equivalent groups beyond the range of the granite's influence might well have proved impossible had it not been for the wealth of connecting exponures. The limestones suffer most from this 
type of alteration, and are converted into calc-silicate hornfelses for distances ranging from a quarter to two miles, measured from the various granite margins.

Apart from such differences as result from metamorphism, the individual groups, with the exception of the Leven Schists, maintain a wonderful constancy of facies throughout the whole of the district. In the case of the Leven Schists, the Banded Series, which is generally quite subordinate to the phyllitic portion of the group, assumes an altogether exceptional prominence in the outcrop between the Ballachulish Granite and the southern margin of the map.

The main structural features of the district are presenfed in outline in Fig. I 2. Owing to repetition in recumbent folds, rocks included in groups $x-6$ occur on two very different structural levels in the district now considered. On the lower level they occupy the heart of the Appin Fold, and on the higher level that of the Ballachulish Fold; henceforward we shall always speak of them as constituting, in these two positions, the Appin and Ballachulish Cores respectively. It will be realised at once that the definition of a fold-core by reference to any particular set of rock-groups is essentially arbitrary, but the convention adopted here will be found very serviceable in grasping the structure of this complicated region.

In addition to the two more important cores mentioned above we may recognise a minor core, that of Aonach Beag, made up entirely of the Ballachulish Limestone (6). This Aonach Beag Core may be regarded as an apophysis of the Ballachulish Core, occurring on a slightly lower structural level than the latter.

The Appin, Aonach Beag, and Ballachulish Cores all gape towards the north-west and close towards the south-east. They are, of course, accompanied by complementary fold-cores gaping and closing in the reverse sense, and constituted of the groups 7-9. These complementary fold-cores have not been given special names, but three of them are distinguished in Fig. I 2 by the following simple device : all rocks belonging to groups 7-9 are fndicated by stippling, and the density of this stippling is varied in accordance with purely structural considerations. On this understanding Fig. 12 explains itself.

The extensive underground continuation of the Appin Core which is shown in Fig. I 2, as obtaining in the southern portion of the district, has not been definitely established. It is probable, however, that the highly metamorphic limestone in the south-east corner of the map near Loch Dochard belongs to this core.

The Ballachulish Core is much more fully exposed than the Appin Core, for it has been bent into a great basin-shaped structure, around the rim of which its outcrop can be traced. The evidence is partially obscured by the lavas of Glen Coe and the granite of Etive, but there is this compensation : the great 


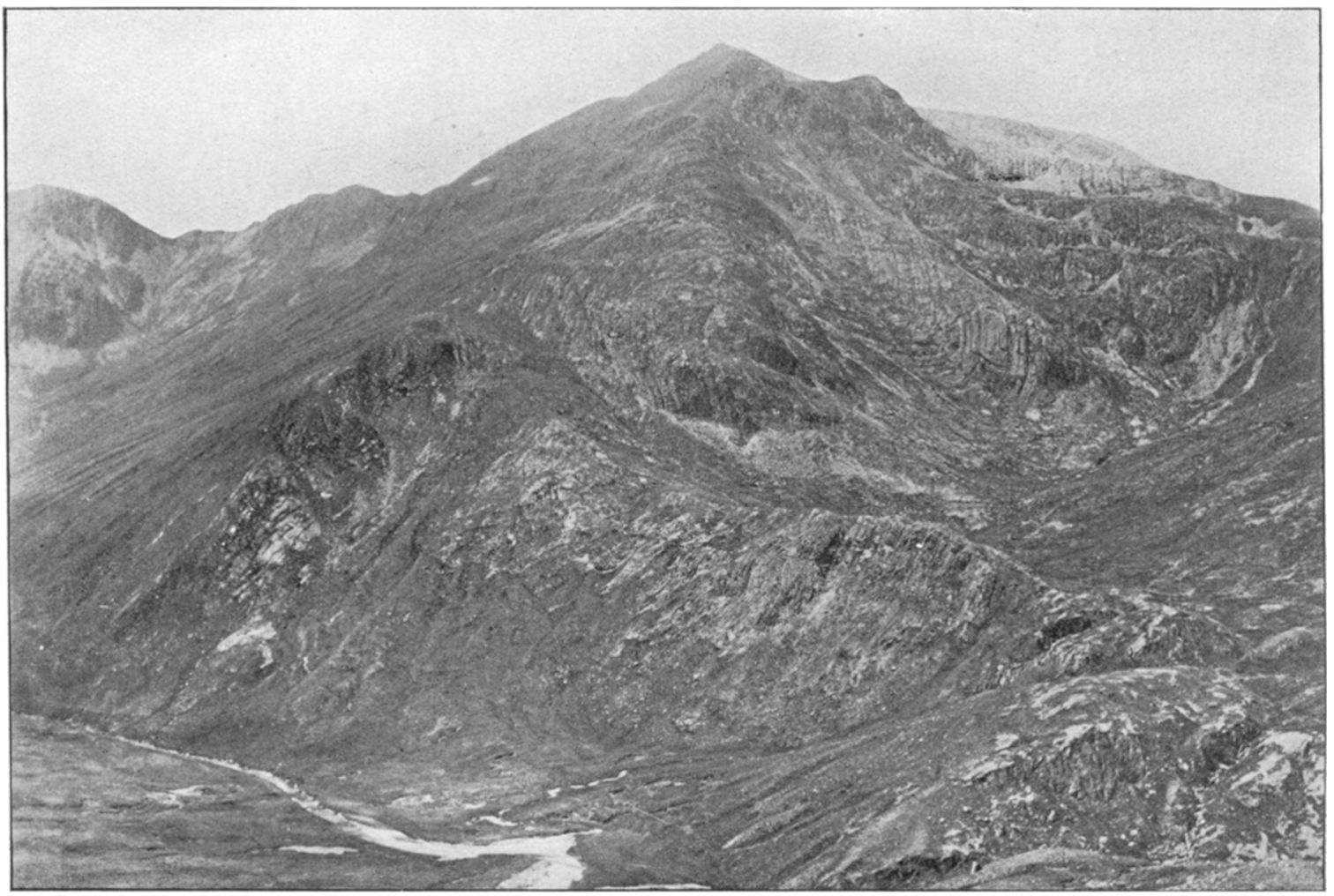

Folded Glen Coe Quartzite and Leven Schists, Sgor a' Mhatm, Glen Nevis. 
cauldron subsidence which has led to the preservation of the Glen Coe lavas has materially enlarged the scope of the basin which holds the Ballachulish Core. Reckoning from the gape of the Ballachulish Core, on the north side of Loch Leven, to the exposure of its taper end in Allt Coire an Easain, at the extreme eastern end of the cauldron subsidence, we are driven to admit a minimum extent of twelve miles for the Ballachulish Fold.

Perhaps the most picturesque feature in connection with this wonderfully extensive Ballachulish Core is the glimpse we get of it through the Windows of Etive, midway between Ballachulish and Allt Coire an Easain. The exposures thus afforded are of great value in piecing together the structure of the district. Of much more importance, however, in this connection, is the section afforded by the Stob Ban ridge at the northern limit of the outcrop of the Ballachulish Core. Here the great basin structure holding the core has narrowed down to a single syncline, and finally rises into the air.

This much can be gathered from an inspection of Fig. I 2 ; further details are supplied by the sections of Plates XXVI and XXVII.

Here it becomes evident that the limbs of the recumbent folds are frequently replaced by fold-faults, or slides, as we term them for brevity, which have given freedom of development to the folds themselves.

The Fort William Slide (Pl. XXVI, Sections A, C, and D) may be taken as typical of these fold-faults. The slide has been detected as a result of mapping, for it greatly reduces or altogether cuts out the Glen Coe Quartzite (8), the Leven Schists (7), and occasionally the Ballachulish Limestone (6) in the lower limb of the Appin Fold. It is not marked, however, by any conspicuous phenomena of mylonitisation such as characterise the well-known thrusts of the North-West Highlands; doubtless this somewhat disconcerting feature is determined by the intimate connection which obtains between the sliding, the folding, and the metamorphism of the schists in this part of the country.

Just as the lower limb of the Appin Fold is in large measure replaced by the Fort William Slide, so also the lower limb of the Ballacbulish Fold is in large measure replaced by the Ballachulish Slide (Plates XXVI and XXVII, Sections $\mathrm{D}-\mathrm{H}$ ). The latter has been detected in every section which, south of the Lairigmor Valley, shows the relations of the Ballachulish Core to the underlying rocks.

In all these sections, from Ballachulish to Allt Coire an Easain, fourteen miles across the strike, the slide cuts out a great thickness of Leven Schists, so that the displacement involved must amount to at least fourteen miles; the proved displacement of the Moine Thrust in the North-IVest Highlands is, it will be remenbered, 
only ten miles, but this is probably not more than a small fraction of the whole.

Considering the great displacement involved in the Ballachulish Slide, it appears certain that this structure cannot really die out in the country north of the Lairigmor Valley. The failure to detect it in this part of its course probably indicates that sliding here has merely replaced one part of the Leven Schists by another part of the same group, instead of by Glen Coe Quartzite. Such is the case, indeed, all the way between Loch Leven and Glen Creran, but here the phenomenon can easily be demonstrated, thanks to the local prominence of the Banded Series of the Leven Schists. This Banded Series has, in fact, in the southern district, replaced the more phyllitic portion of the Leven Schists beneath the Ballachulish Slide along the whole course of its outcrop.

If all the slides of Lochaber and Appin were homologous to the Fort William and Ballachulish Slides it would be justifiable to call them thrusts, on account of the well known prevalence of thrusts in folded mountains. But such is not the case. There are many important slides in the district which are complementary to the two slides just mentioned. For instance, in Pl. XXVII, Section G, while the slide $S^{\prime}$ is homologous to the Ballachulish Slide (B. S.), the slides $S^{\prime \prime}$ and $S^{\prime \prime \prime}$ are complementary in nature. So, too, in Sections A-D the Meall a' Bhuirich Slide is clearly complementary to the Fort IVilliam Slide. Another good example of the complementary series is afforded by the Glen Stockdale Slide, traced from near Appin to the Ballachulish Granite. It appears then that sliding has occurred in certain instances in both limbs of one and the same recumbent fold. It is therefore due to something more than mere overthrusting. It is a complex accommodation phenomenon of a type peculiar, perhaps, to the interior portions of folded mountain chains. In fact, the cores of many of the recumbent folds have been squeezed forward so that they have virtually reacted as intrusive masses.

One last feature may be noted before this summary is brought to a close. The earlier-formed cores and slides have suffered extensive secondary corrugation of isoclinal type. In connection with the continuance or recrudescence of movement thus indicated, it is interesting to note that the metamorphism of numerous small intrusions of hornblende schists in the Glen Creran district is probably connected with a late phase of the disturbances. These schistose igneous rocks, to judge from their field distribution, were intruded after differential movement along the Ballachulish Slide had come to an end.

A matter of detail still remains to be considered. Since their first publication the sections of Pl. XXVI have been somewhat modified in respect to the much greater extent now assigned to the fold of Leven Schists lettered "h." That such modification 
would probably be required was realised at the time of drawing the original sections, but as I had little personal knowledge of the northern part of the outcrop of this fold, it seemed preferable to start on as small a scale as possible, and to expand in later representations if this should still appear desirable.

On indirect evidence the fold " $h$ " has been, from the first, regarded as anticlinal, and this conclusion, though not yet established, has lately been strengthened as a result of a renewed examination of the subsidiary fold of Leven Schists which joins the main fold " $h$ " on its eastern side, north of the Kinlochleven Reservoir.

This subsidiary fold has been mapped by Mr. Anderson as terminating before reaching the Moor of Rannoch Granite. $A$ visit to the locality shows that the Leven Schists, near the end of the fold, as mapped, are everywhere pitching persistently south-west at an angle of about $45^{\circ}$. It is a pity that the exposures showing the termination of the fold are not clearer (there is a thick covering of morainic débris near the granite margin), but at the same time it is difficult to resist the suggestion that this subsidiary fold is of anticlinal form. There is thus afforded a certain amount of additional indirect evidence in favour of the view already advanced in regard to the anticlinal form of the main fold " $h$."

It therefore still seems justifiable to draw the fold " $h$ " in P1. XXVI as an anticline, but the question remains : in which direction and for what distance did this anticline extend above the present surface of the ground? Now, as Glen Coe is approached, a persistent south-westerly pitch is encountered, which, aided by the Glen Coe boundary fault, is responsible for carrying the outcrop of the Ballachulish Core eastward through Coire Mhorair to Allt Coire an Easain. The deflection of the outcrop of the fold " $h$ " when it comes into this region of southwesterly pitch and its probable reappearance, south of the Moor of Rannoch Granite, only two miles west of Loch Tulla, render it extremely probable that this fold has an eastward extension of some five miles across strike.

It has seemed desirable at the present time to give expression to this probability, and the Sections A-D of Pl. XXVI bave been altered accordingly. The attenuation, or absence, of the Glen Coe Quartzite between the Eilde Flags and the Leven Schists, as exposed in this fold, has already been taken as furnishing evidence of the existence of a slide, the Meall a' Bhuirich Slide, along this line of junction; it is supposed that this slide developed at an early stage of the movements before the fold " $h$ " had begun to form. The fold " $h$," therefore, in spite of its magnitude, is regarded as a secondary structure in the tectonic development of the district. 


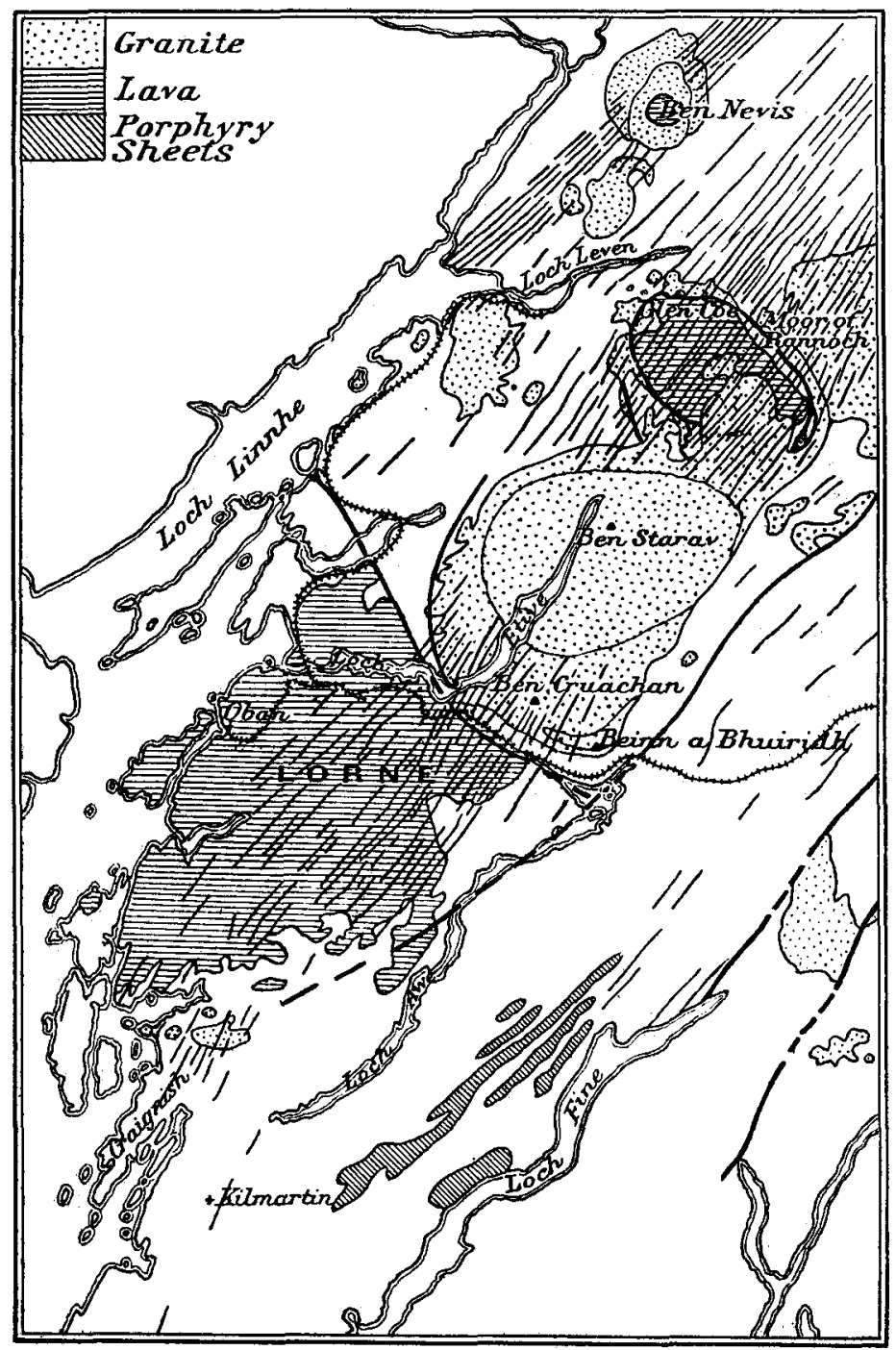

FIG. I3.-SKETCH-MAP OF THE VOLCANIC DistRIC' OF ARGYLLSHIRE AND INVERNESS-SHIRE; SHOWING THE Distribution OF DYkes iN Relation to THE EtIVe and Nevis Granite Complexus. Dykes shown by Light, and Faults By Heavy, Black Lines. Based mainly upon $H$. B. Maufe and $H$. Kynaston. 


\section{III.-THE CAULDRON SUBSIDENCE OF GLEN COE.}

The Glen Coe volcanic rocks are of Lower Old Red Sandstone age, as is indicated by the plants, Psilophyton and Pachytheca, found in sediments occurring at their base. They consist in the main of a great pile of lavas, including augiteandesites, hornblende-andesites and rhyolites. There is no evidence of an orderly sequence in the eruptions which gave rise to these lavas; on the other hand, it seems probable that the district was supplied from various centres which were independent of one another in regard to the type of material erupted, even though their periods of activity overlapped to a very considerable extent. Agglomerates are infrequent in the Glen Coe succession and are difficult to separate from associated breccias of sedimentary origin.

The volcanic rocks were accumulated in striking unconformity on an irregular eroded land surface composed of the schists described in the previous section. The deposits commonly intervening hetween the lavas and this old floor comprise scree-like breccias, formed of the shattered local rocks, and also boulder conglomerates, such as may have been accumulated by torrents. Thin lenticular beds of shale, grit and breccia recur at intervals in the succession, while horizontally bedded silt often reaches down into the crevices of individual lava flows. These sediments, so far as they are waterborne, are due probably to strcams and temporary lakes, for the eruptions on the whole appear to have been subaerial.

The volcanic rocks occupy the major portion of a great cauldron subsidence, of oval outline, measuring 9 miles in length by 5 in breadth. Even near the boundary fault of the subsidence the rocks have sunk well over rooo ft., while the total displacement has been materially increased by sagging of the central parts. The main features of this cauldron subsidence are illustrated in the sections of Pl. XXVII and in the map, Pl. XXIII.

One fifth of the circumference of the cauldron is now obscured, it is true, by an offshoot of the Cruachan Granite* which has invaded the foundered area from the south, and obliterated the boundary fault for a distance of about 4 miles. But it is obvious that this fault once completed its circuit, for the truncated ends of the dislocation would meet one another in a perfectly natural manner if continued forward across the gap now occupied by granite.

The movement of subsidence was at times of a somewhat unusual and probably very rapid type, for a flinty crush-rock can be observed at some points at least along the line of the dis-

\footnotetext{
* The Cruachan Granite forms the outer rim of the Etive granitic complex; the inner core of this complex is known as the Staray granite. The two are grouped together in the map, Pl. XXIII, but are separated in Fig. :3.
} 
location. From the local evidence, and from analogy with other regions, it appears that this crush-rock owes its flinty character to extreme trituration accompanied by incipient fusion due to heat developed through friction in the plane of the fault.

The boundary fault, where it has not been obliterated by the Cruachan Granite - that is, along four-fifths of its original extent-is surrounded by a discontinuous complex known as the faultintrusion*. This complex includes both granites and coarse porphyrites, and its inner margin is defined by the boundary fault of the cauldron subsidence, in a manner that is almost mathematically exact. In several notable instances large independent masses of the intrusion show smooth, clean-cut margins against the fault plane, and ragged transgressive outer margins against the schists beyond. Moreover, while innumerable small intrusions belonging to the complex are scattered through the zone outside the fault, not more than three or four insignificant examples are found inside. The breadth of the intrusion zone, measured outwards from the fault, may be roughly taken as a mile.

Along its outer irregular margin, the fault-intrusion is sometimes obviously chilled and sometimes not; along its inner smooth margin against the fault plane it is invariably chilled. In like manner, the alteration induced by the fault-intrusion is almost entirely restricted to the zone external to the fault, where it is often very evident indeed.

The distribution of the fault-intrusion on each side of the boundary fault is so strikingly asymmetrical that we are bound to seek some element of asymmetry in the conditions which governed the intrusion. Movement acting either before, after, or during the period of intrusion appears to be the only possible cause of asymmetry admitted by the conditions of the problem.

Movement before the intrusion might lead to asymmetry by faulting down a relatively impenetrable type of rock on the inside of the cauldron subsidence against a penetrable type on the outside. If, for instance, the whole of the foundered area were occupied, at the present surface, by lavas thrown down against schists outside, this explanation would appear extremely reasonable. But, as a matter of fact, the lavas have been so far removed by erosion that along half its course the fault is seen separating schist from schist. More than this, it is possible to recognise inside the cauldron the displaced equivalents of the very same members of the schist succession as occur outside. The asymmetrical distribution of the fault-intrusion is, therefore, not determined by any peculiar character of the down-faulted rocks ; and accordingly it cannot be due to movement antedating the intrusion.

* The Moor of Rannoch Granite is of earlier date than the fault-intrusion. The margin between the two is indicated on Pl. XXIII and Fig. I3. 

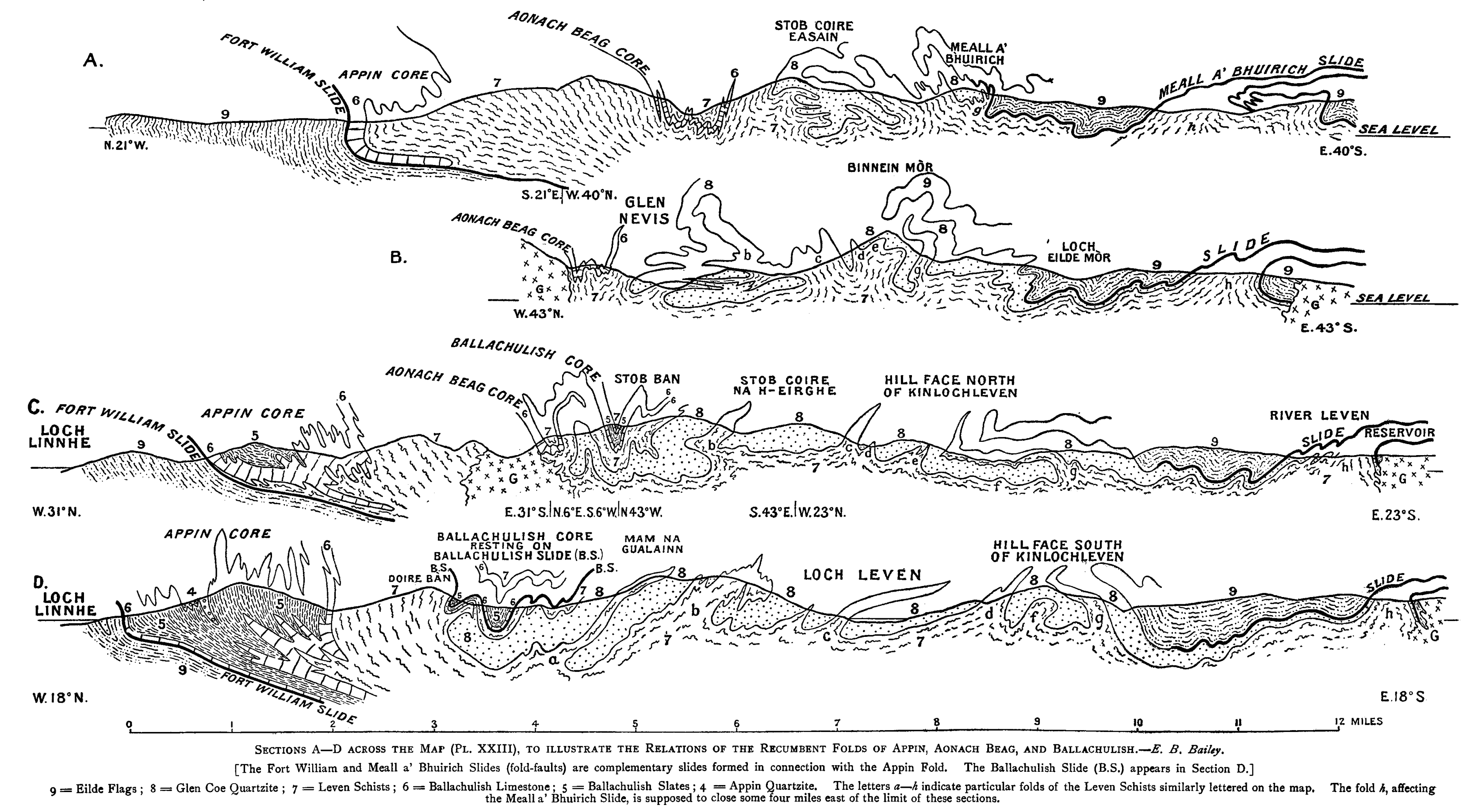
$9=$ Eilde Flags $; 8=$ Glen Coe Quartzite $; 7=$ Leven Schists; $6=\begin{gathered}\text { Ballachulish Limestone } ; 5=\text { Ballachulish Slates; } 4=\text { Appin Quartitite. The letters } a-h \text { indicate particular } \\ \text { the Mealla' Bhuirich Slide, is supposed to close some four miles east of the limit of these sections. }\end{gathered}$ 
Faulting after intrusion is, on the other hand, ruled out of court, since the fault-intrusion is chilled against the fault plane.

We are thus led to regard the faulting and the intrusion as contemporaneous events. They represent two aspects of a single adjustment. The magma welled up around the subsiding mass like the liquor in a full bottle when the stopper settles home. The slowly rising stream found in the fault plane its easiest avenue of escape, and from this channel, we may suppose, it tended to spread out symmetrically into the rocks on either side ; but any portion which trespassed into the sinking mass was, by a continuation of the subsidence, carried down. Thus contemporaneous movement along the fault supplies the element of asymmetry which is the very essence of the problem. It delayed the entrance of the intrusion into the dowrthrown mass, in comparison with the zone lying immediately outside. Within limits, this effect would certainly be curnulative, since each fresh invasion of the outer zone furnished an additional channel for the upward and outward advance of the ascending magma.

Contemporaneous movement also explains the relative freedom from thermal alteration of the downthrown mass, for the latter to some extent carried its comparatively low initial temperature downwards with itself.

A surprising feature of the Glen Coe phenomena is the frequency with which the fault surface is found smooth and unbroken in contact with the fault-intrusion. This relation must be considered in connection with the fact that the fault-intrusion carries an extraordinary number of xenoliths. It seems probable that the magma has advanced upwards largely by the process known as stoping, so strongly advocated by Daly.* Doubtless the solid schists were heavier than the ascending magma, and accordingly tended to break off along their numerous planes of weakness and sink as fragments into the intrusion. But of all the planes of weakness the fault plane would be predominant, and accordingly it would tend to be stripped clean and bare when exposed to the operation of stoping, regulated, as in this case, by conditions strongly favouring asymmetry.

There is clear proof that the cauldron subsidence was not effected in a single stage. The evidence for this is best displayed on the northern margin of the cauldron, where another parallel branch of the fault, of manifestly early date, exists. Like its later companion, this early branch has its own special band of flinty crush-rock and its own special fault-intrusion. The latter, during the movements of subsidence connected with the production of the inner branch of the fault, has itself been sheared, and in many cases broken down, with the production of flinty crushrock. Another good example of an early branch of the fault, 

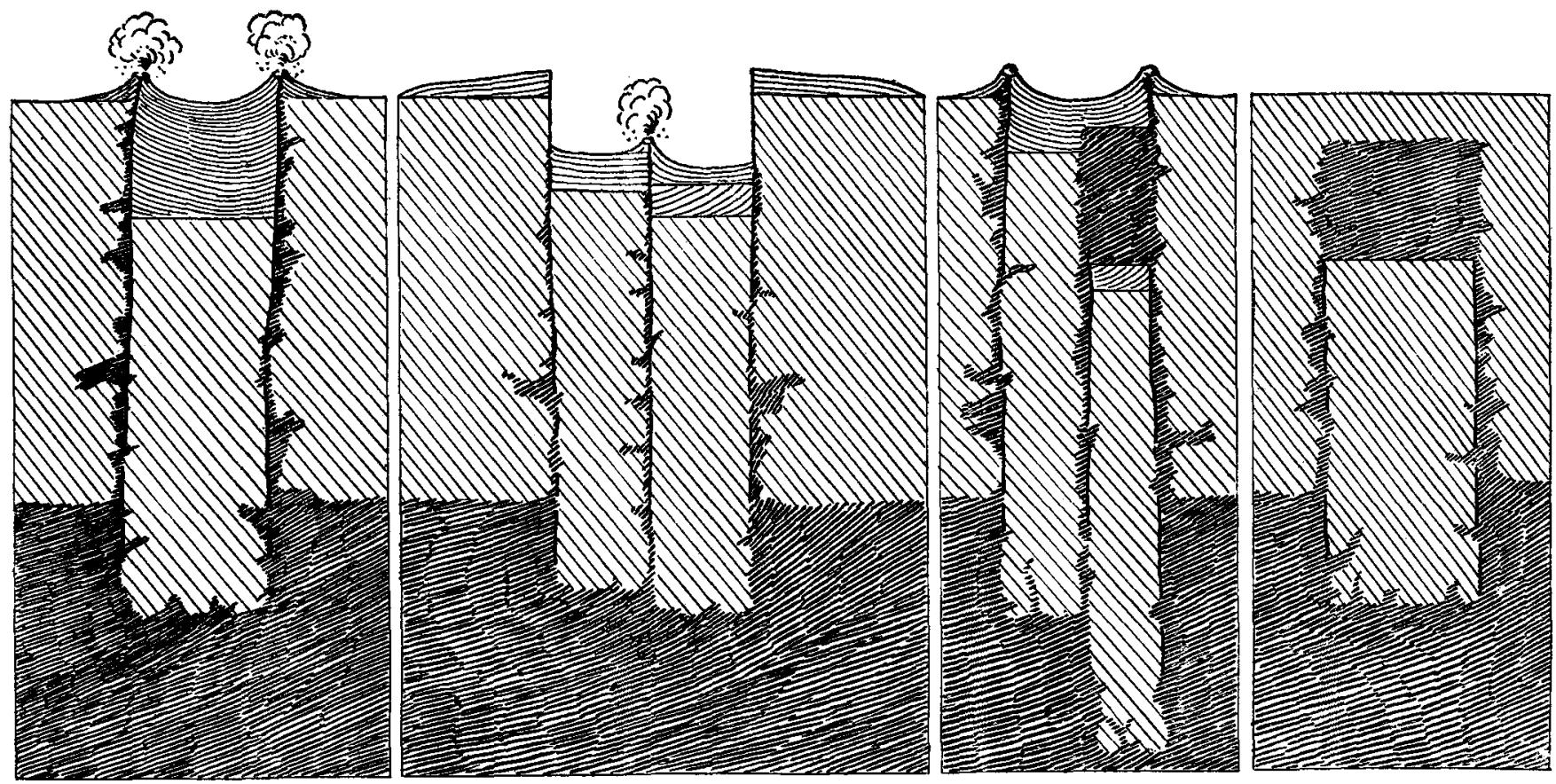

Fig, I4.-Diagram illustrating Subaerial and Subterranean Cauldron Subsidences, accompanied by Volcanic and Plutonic ACCumulations of IgNeOus Rock.-After C. T. Clough, H. B. Maufe, and E. B. Bailey. 
accompanied by an early fault-intrusion, presents itself on the east side of the cauldron. Here the older branch occupies the interior position.

The evidence of repeated subsidence and marginal intrusion thus afforded suggests that the lavas themselves may have been fed by early fault-intrusions rising round about the cauldron.

Unfortunately there is an absence of direct evidence bearing upon this point, and all that can be said about the sources of supply of the lavas is that they were certainly near at hand. This is shown alike by the capricious variations of the volcanic sequence already referred to, and by the presence, both in the lavas and in the adjacent schists, of a local set of felsite and andesite dykes of irregular direction and obviously early date.

The fault-intrusions surrounding the Glen Coe cauldron are, in all probability, merely rather early off-shoots of the Cruachan magma. The latter has penetrated the foundered area from the south, and underlies the lavas of the central district, in which it causes marked contact alteration. It cuts across lavas 2,000 feet thick, without showing any indication of arching or tilting them. This lobe of the Cruachan Granite is confluent to the south with a much more extensive mass which, with its great core consisting of the more acid Starav Granite, forms the huge Etive Boss, I 5 miles long and ro miles broad (Fig. 13).

The northern lobe of the Cruachan Granite, although it must have entered the precincts of the Glen Coe Cauldron after subsidence in block had ceased, merges with the fault-intrusion at the eastern side of the cauldron. The interval of respite in the plutonic history of Glen Coe appears, therefore, to have been but brief-sufficiently long, however, to permit of the local consolidation of the fault-intrusion, as, for instance, where the latter crosses Glen Etive. It is difficult, in fact, to avoid the conclusion that the invasion of the Cruachan Granite in this instance has not interrupted, so much as modified, the history of subsidence of the Glen Coe Cauldron. It appears probable that, since its roof shows no signs of tilting up, its floor has sunk down to make room for the invading magma.

But if it be admitted that this semi-detached northern mass of the Cruachan Granite, lying in the Glen Coe area of subsidence, is merely the plutonic infilling of a subterranean cauldron, it is extremely reasonable to interpret the southern mass in the same manner also. But to discuss this matter and the relations of the later Starav Granite, which is also believed to occupy a subterranean cauldron, would take us too far afield. The mechanism of subterranean and subaerial cauldrons is sufficiently indicated in Fig. I4. It must not be supposed, however, that this figure is anything more than a rough diagram. In particular it seems likely that the sinking plugs of solid rock beneath the various cauldrons must become more and more broken up, and perhaps Proc. Geol. Assoc., Vol. XXII, Part 4, IgII.] 
dissolved at increasingly lower levels, so that eventually great tubes are formed, consisting largely of molten material.

Between the periods of intrusion of the Cruachan and Starav granites there intervened an important epoch marked by the injection of a great host of parallel north-north-easterly dykes (Fig. I3). For the most part they are porphyrites, and obviously closely related in composition to the granites.

The dykes are "regional" in their constancy of direction, for they exhibit not the slightest tendency to radial arrangement ; but they are "local" in their marked concentration into a definite belt with the Etive mass at its centre.

The dykes of this suite definitely add their own thickness to the width of the country which they traverse. Their injection has been accompanied by an opening of fissures in the country rock, and an outward displacement of the walls of these fissures; at the same time, it has not been accompanied by faulting. The regional stress thus indicated must clearly have been of the nature of a relative tension orientated at right angles to the direction taken by these dykes. Since the dykes are parallel, the growth of tension in the district must have been repeatedly in the one direction, throughout a protracted period. The dykes represent the intermittent response to the growth of the regional stress, and their moderate breadth indicates that, in each case, the tensional earth-stress, co-operating with the pressure of the magma, was accommodated by a moderate displacement of the walls of the fissure.

Following Marcel Bertrand and Harker, we are inclined to seek the cause of this long-continued growth of tension in some widespread contemporaneous depression of a neighbouring portion of the earth's crust. A redistribution of stresses must accompany such a depression; an extensive peripheral region must be involved; and masses which have long been stagnant must stretch and yield in accordance with the new conditions of equilibrium. Viewed in this light, the parallel dyke fissures have a distinct analogy with the transverse fissures of a glacier.

The local concentration of the porphyrite dykes in relation to the Etive centre can now be interpreted with some degree of probability. We have already suggested that beneath the granite exposed at the surface there extends a tube, largely filled with plutonic rocks, which reaches down to the general magma basin below. Probably the contents of the tube, at no great distance down, were still molten during the dyke phase, as is indeed suggested by the later uprising of the Starav Granite. The regional stresses, tending by their action to produce extension, would find in this great tube a plastic body, of large cross section, incapable of resisting deformation. Its weakness would be the dominating subterranean feature of the whole district; its yielding a sufficient cause to locate the two great swarms of dykes which 

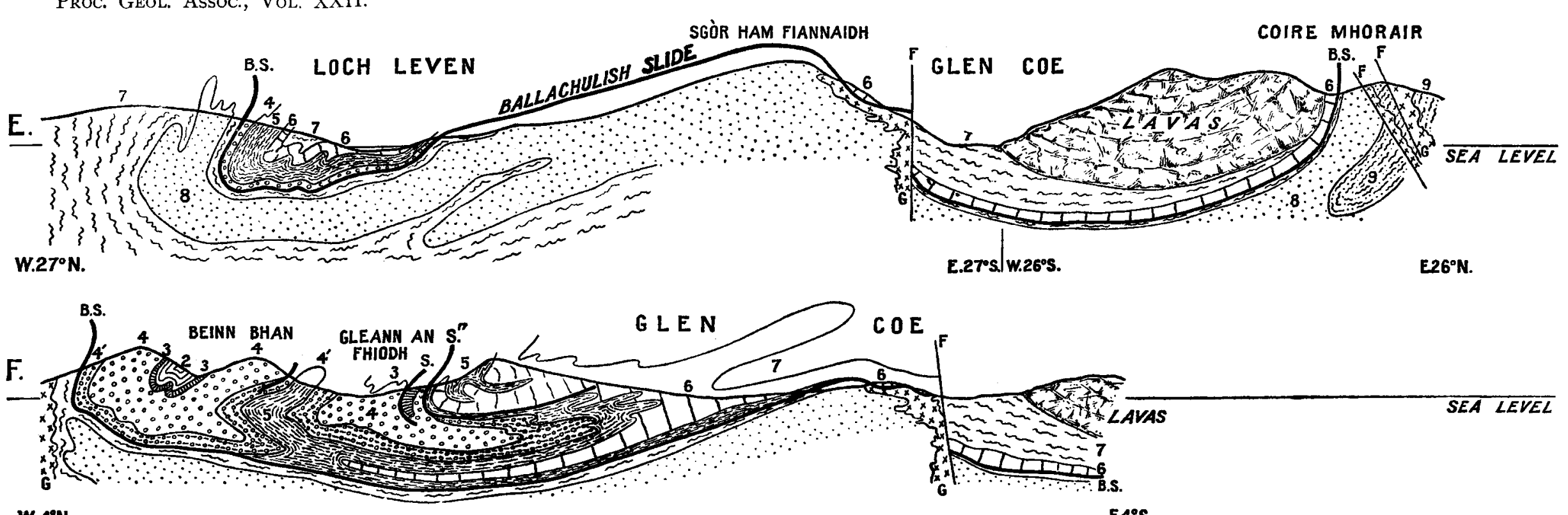

W.4*N.

E26N.

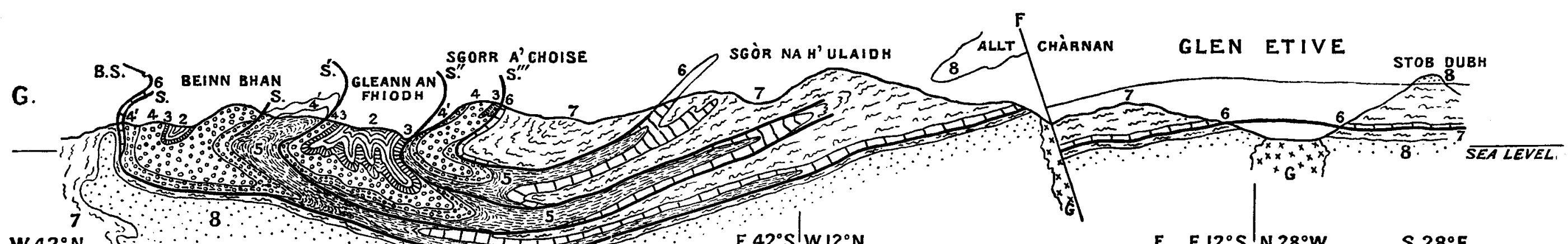
W.42 ${ }^{\circ}$.

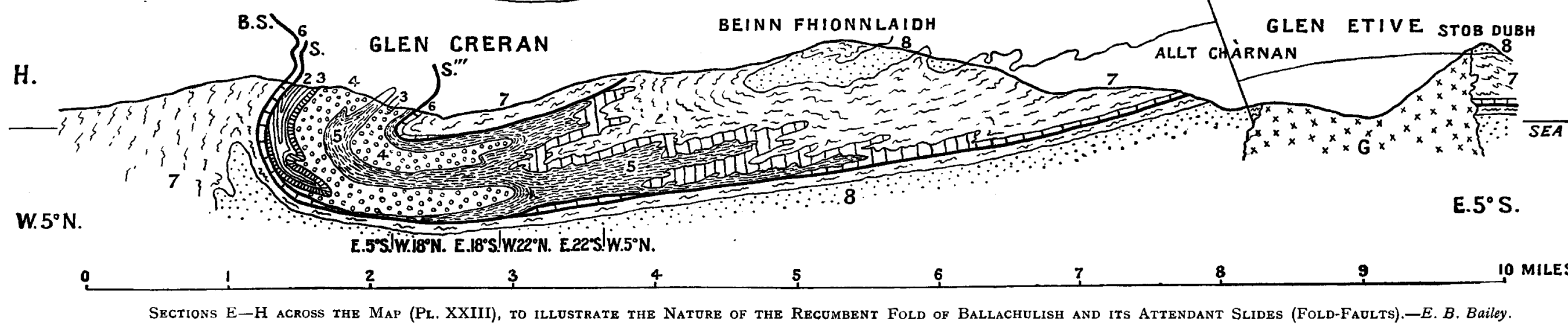

[The downthrown region in the eastern part of these sections belongs to the Cauldron Subsidence of Glen Coe. Sections $\mathrm{G}$ and $\mathrm{H}$ cross the Windows of Etive. The scale, $\mathrm{r}$ inch to the mile, vertical and horizontal,

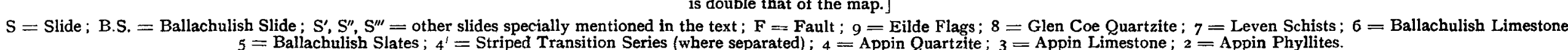


are now separated by the Starav Granite, but which, at the time of their formation, were probably more or less continuous.

We may now pass on to consider Mr. Maufe's observations on Ben Nevis, where many of the phenomena of Glen Coe are repeated, though with certain important variations.

\section{IV.-THE IGNEOUS HISTORY OF BEN NEVIS.}

The Ben Nevis massif is geologically divisible into three welldefined concentric zones (Fig. I 5), which, reckoned from without inwards, are as follows :

(I) An outer discontinuous ring consisting of granite steeply bounded against intensely contact-altered schists outside; near the schists this granite is grey in colour and contains augite, but for the most part it is a medium-grained pink rock with lateformed phenocrysts of perthitic orthoclase.

(2) An inner continuous ring consisting of granite of somewhat later date; it has steep intrusive exterior and interior margins, and is more acid in composition than the outer granite, from which it is further distinguished by its finer and more evengrained texture, and its smaller proportion of dark constituents; along its steep interior margin the granite chills to a felsitic rock with vertical, streaky flow-structure.

(3) A central core consisting of some 2,000 feet of volcanic rocks and an unknown thickness of underlying schists; the volcanic rocks are hornblende-andesite lavas, with subordinate agglomer. ates; a few thin bands of associated sediment are also found, and the whole mass is disposed in a basin with steeply tilted margin; at two localities along the edge of the basin the schists are exposed to view, in one case forming a strip 200 yards long.

A glance at Figs. I 3 and $I_{5}$ shows that the Ben Nevis granite has a retinue of dykes comparable with that of the Etive complex ; these dykes are porphyrites and lamprophyres, the former predominating. They cut and chill against the outer older granite, but, in the majority of cases, are cut across by the inner later granite; a few penetrate the latter, but only for a short distance. Thus, as in the case of the Etive complex, the main dyke phase intervened between the intrusion of the two granites; the only point of difference is that in Ben Nevis one can prove the existence of a second dyke phase after the intrusion of the younger granite.

Mr. Maufe's conclusions may be stated in his own words :-

"Although the age of the volcanic series has not been fixed by the discovery of fossils in the interbedded sediments, the similarity of the latter and of the accompanying igneous rocks to those of Glen Coe and of Lorne compels us to believe that the lavas of Ben Nevis were erupted in Lower Old Red Sandstone 


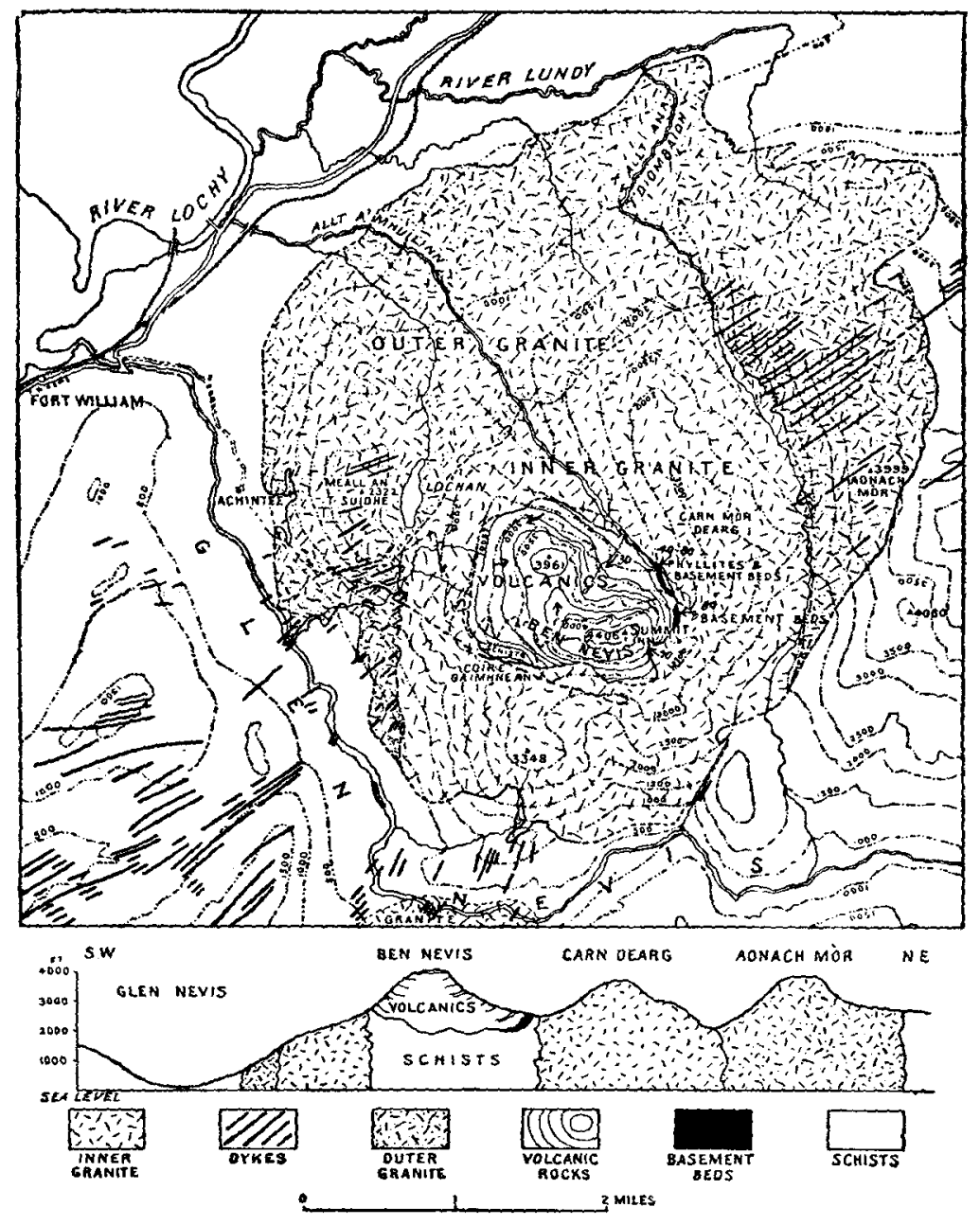

Figr. 15.-Geological Map and Section of Ben Nevis.-After H. B. Maufe. (Tepreduced by permutission of the Controller of H.M. Stationery Office.) 
times. * Further, it is patent, from the foregoing description, that the structure of Ben Nevis admits of an interpretation similar to that applied to the Glen Coe and Etive igneous centres.

"The outer granite with its steep walls may be conceived as filling the void created by the gravitational sinking of a subterranean block into the underlying magma. Before the central [inferior] parts of this column of igneous rock were completely consolidated, tensional stresses acting in a N.W. and S.E. direction developed fissures normal to their direction, and the plutonic focus acted as a lateral dyke-injector.

"Subsidence, now confined to the central area, again ensued, and was accompanied in complementary fashion by the uprise of the inner granite. But then an event occurred which, so far as we can tell, is peculiar to Ben Nevis. The roof of the subterranean cauldron gave way, and a block of schists, with its burden of lavas, subsided into the still liquid inner granite. The motion developed a streaky flow-structure in the magma, which itself became chilled against the cool descending mass. The latter, during its subsidence, buckled into its basin shape by reason of the friction on its walls, and its cracked margin, on coming into contact with the magma, was penetrated by veins of granite. The sinking block in its descent must have dropped over $\mathrm{I}, 500 \mathrm{ft}$. We are thus led to the conclusion that the lavas of Ben Nevis, in spite of their great altitude, owe their preservation, like those of Glen Coe, to subsidence. The local igneous history seems to have closed with the injection of a few more dykes which pierce the margin of the inner granite.

"A point which is not at all clear is the relative age of the volcanic series and of the older granite. By analogy with other areas we may suppose that the volcanic rocks were extruded first. If this were so, it is perhaps remarkable that not a single dyke has been found cutting through the volcanic rocks. At the same time the schists lying beneath the latter are equally free from dykes, though their outcrop runs at right angles to the swarm of dykes, and is sufficiently long to have included several of them if spaced at average intervals. We can only surmise that the volcanic mass, in its original position, was above the level at which dykes were injected from the subterranean cauldron.

"Although a close analogy with the igneous centres lying to the south has been shown to exist, there is not on Ben Nevis that definite evidence of faulting accompanying the uprise of igneous magma which Glen Coe affords, for the occasional brecciation of the schists on the edge of the granite mass cannot be adduced as

* It might, perhaps, be safer to say "during soue part of the great period of igneous activity which extended into Lower Old Red Sandstone times." Locally, at all events, in the Highlands this period appears to have started in Silurian times, since at Stonehaven pebbles of rhyolite and hornblende andesite are abundant in conglomerates assigned to the Downtomian. Cf. R. Campbell, "Preliminary Note on the Geology of South-Eastern Kincardineshire," Geol. Mag. 19II, pp. 67, 68.-E.B.B. 


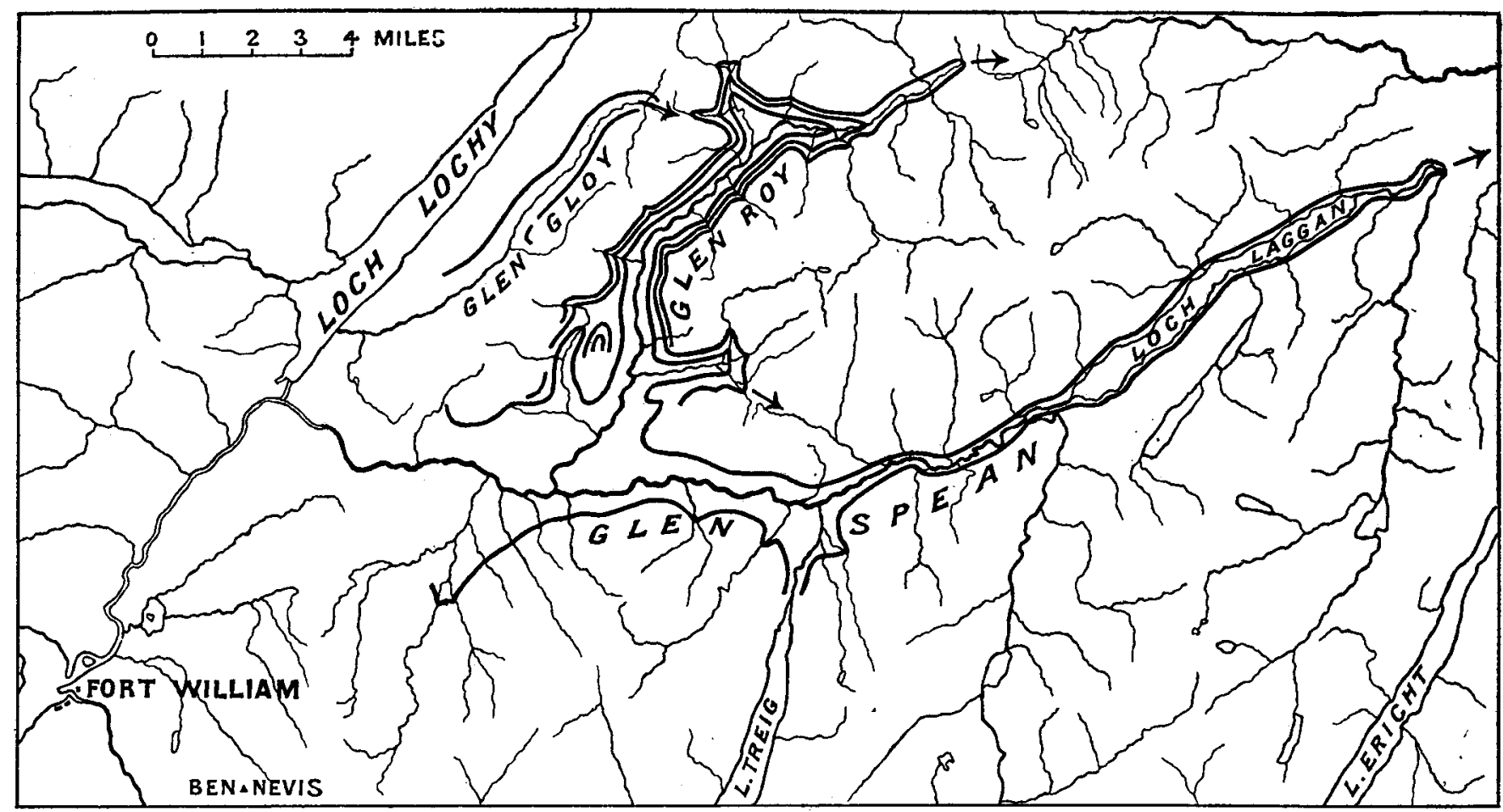

Fig. 16.-MAP of the Fort William District and the Parallel Roads of Glen Rov.-E. B. Bailey, after T. F. Famzeson andothers. 
proof of it. In this connection we may refer to the deflection of the outcrops of the belt of limestone on the western margin of the granite [PI. XXIII]. The outcrops of limestone, as they approach the granite on either side, advance in a north-westerly direction. At a first glance, the deflection might be attributed to the pressure of the invading magma. When, however, it is realised that the limestone, although packed into tight folds, forms a bed which dips gently towards the south-east, it will be seen that the advance of the outcrop towards the north-west may be due to nothing more than a slight sag of the schists around the margin of the granite. Such a sag may well have been brought about by the drag at the edge of the block which sank to admit the granite magma."

\section{V.-THE PARALLEL ROADS OF GLEN ROY.}

The fame of the Parallel Roads of Glen Roy has been so loudly sung that one is apt to approach them with a certain anxiety. But all misgiving vanishes when, after travelling a short way up the glen, one sees the three terraces traced along the hillsides with a simplicity which defies pictorial exaggeration; the only feeling that remains is that "Behold, the half was not told." To get some impression of what the Parallel Roads look like in nature one may, however, turn to Macculloch's plates (Trans. Geol. Soc., vol. iv, I8I7) or to Sir Archibald Geikie's sketch in The Scenery of Scotland, rgor, p. 291. The extent of the roads and their relation to the valley system of the district are roughly indicated in Fig. 16.

The Parallel Roads are old beach lines. There are three of them in Glen Roy, at levels of I, I 55, I,077, and 862 feet respectively above mean water-level at Liverpool. A similar terrace at $\mathbf{r}, \mathbf{I} 73$ feet is also met with in the adjacent valley of Glen Gloy.

Each terrace definitely corresponds in altitude with a deserted outflow, so that it seems well-nigh impossible to escape the inference that each of them marks an ancient lake margin. Indeed, Dick-Lauder, in 1818 , adopted this view of the matter after accurately establishing the position of the outflows of all the lakes involved, save only that which corresponds with the middle terrace of Glen Roy. The difficulty, of course, which had to be faced during what may be termed the pre-glacial days of geology was to explain the complete disappearance of the barriers required by the lake hypothesis. This difficulty, indeed, seemed insuperable, and led Darwin in 1839 to propose a marine origin for the beaches, and to suggest that the apparent outflows were in reality straits silted up to the level of the beach lines.

But help was coming, and from an unexpected quarter-from Switzerland, where a new theory was gaining acceptance which 
postulated a former extension of glaciers far beyond their present limits. In this great work, which before long assumed international dimensions, the pioneers were Venetz and Charpentier. It is true that the first suggestion of widely-extended glacial action came from other sources. Charpentier has himself pointed out that Playfair, as early as 1815 , in notes on a visit to the Alps, regarded glaciers as the only agents capable of transporting enormous blocks to great distances without destroying their angularity, and further that he was not afraid of the extent which, under the circumstances, it was necessary to ascribe to the glaciers of bygone days. Goethe too, in the r829 edition of his Wilheln Meister, advanced the same opinion, while Esmark, of Christiania, admitted in 1827 that the blocks of granite dispersed in such numbers through Norway had been conveyed by ancient glaciers. So, too, among the simple mountaineers of Switzerland there were many who realised the true significance of the scratched surfaced and erratic blocks which they encountered far from the terminations of modern glaciers. But no general impression had been produced upon scientific thought until Venetz and Charpentier undertook their researches.

An invaluable supporter of the new views soon arose in the person of the great naturalist Agassiz. The evolution of his ideas on the subject does not concern us here. Suffice it that in I 838 he was able to explain to Buckland that various wellcharacterised phenomena on the south-east slope of the Jura Mountains are the result of ice. Buckland was not convinced until he had examined for himself actual glaciers in the Alps. $\mathrm{He}$ then returned to Agassiz and said that he had seen similar evidences in Scotland and England, where he had grouped them with his other Reliquice Diluviana. As a consequence, in I840, the year of the British Association meeting at Glasgow, Agassiz undertook an extensive tour in Scotland and the North of England in company with Buckland.

The two visited Glen Roy and convinced themselves that a glacial interpretation meets all the circumstances of the case : the mysterious lakes had been imprisoned by glaciers; the lakes have vanished because the glaciers have vanished; the former presence of the lakes is attested by beach lines, that of the glaciers by striæ and moraines.

Agassiz' account of the matter, so long as we are not concerned with details, is quite convincing as we read it to-day, but for a long time it was set aside as little short of ridiculous. Darwin, however, was not disposed to treat it so lightly, and accordingly joined Lyell in persuading Dr. Jamieson to reinvestigate the whole matter in $\mathrm{r} 86 \mathrm{r}$.

Meanwhile, in 1847 , Milne Home, although an antagonist of Agassiz, had strengthened the case for some form of lake hypothesis; he succeeded in locating the outflow channel of the 
Proc. Grol. Assoc., Vol XXII.

Plate XXVIII.

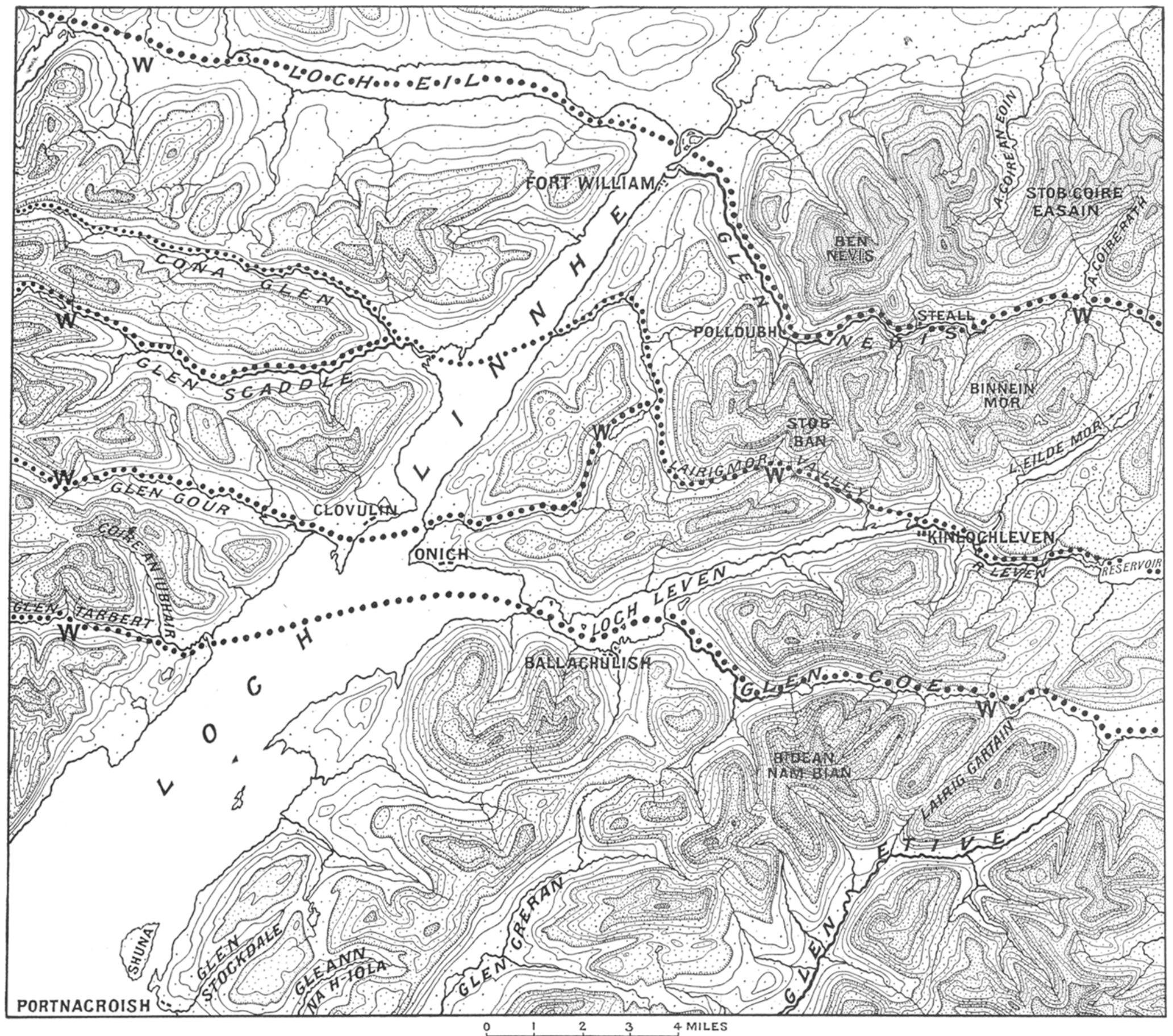

Physiographical Map of the Fort William District. $-E$. B. Bailey.

The lines of dots show the original drainage system, intercepted by shatter-belt valleys (Loch Linnhe and Loch Leven) and by secondary watersheds (W.). Contours every 250 feet. The $1,000,2,000,3,000$, and 4,000 feet contours emphasised by shading. 
mid-level lake of Glen Roy, and he pointed to the evidence of fluviatile erosion which characterises alike this channel and those previously known.

Dr. Jamieson's researches settled the issue once for all. The lakes were undoubtedly impounded by glaciers coming from the west side of Loch Lochy, joined by others draining the valleys of Ben Nevis, and, during the formation of the two upper terraces of Glen Roy, by another emerging from the hollow of Loch Treig. A glance at the map suffices to indicate how the extent for the time being of the Loch Treig glacier determined whether the waters, impounded in Glen Roy by western ice, should escape by the bighest, the intermediate, or the lowest of the three possible overflow channels leading into the eastern drainage system of the country.

It must be realised that these lakes of Glen Roy belonged to a very late stage in the glaciation of Scotland; at an earlier date the whole country was smothered under ice.

\section{BIBLIOGRAPHY.}

I 842. AGASSIZ, LouIs.- "The Glacial Theory and its Recent Progress." The Edinburgh New Phil. Four., vol. xxxiii, p. 2 I 7.

1863. JAMieson, T. F.- On the Parallel Roads of Glen Roy, and their Place in the History of the Glacial Period." Quart. Fourn. Geol. Soc., vol. xix, p. 235.

1909. Clough, C. T., MaUfe, H. B., and BaIley, E. B.-" The CauldronSubsidence of Glen Coe, and the Associated Igneous Phenomena." Quart. Fourn. Geol. Soc, vol. lxv, p. 6I I.

1910. MaUfe, H. B.-" The Geological Structure of Ben Nevis." Summary of Progress for 1909, Mem. Geol. Survey.

I910. BaIley, E. B.- "Recumbent Folds in the Schists of the Scottish Highlands." Quant. Fourn. Geol. Soc., vol. lxvi, p. 586.

IN PReParation.-Sheet 53 of the one inch to one mile map of the Geological Survey of Scotland.

In Preparation.-" The Geology of the Neighbourhood of Ben Nevis and Glen Coe." Mem. Geol. Survey. 